\title{
SUPERVISI AKADEMIK DALAM PENINGKATAN PROFESIONALISME GURU
}

\author{
Atika Yondria Fatmi 17002046
}

Email: atikayondriafatmi@gmail.com

Kata kunci: Supervisi, Akademik, Prefesionalisme dan Guru

\begin{abstract}
ABSTRAK
Dalam artikel ini bertujuan untuk mengetahui tentang bagaimana supervisi akademik dalam meningkatkan profesionalisme guru, dan bagaiman upaya-upaya yang dapat dilakukan dalam meningkatkan profesionalisme guru, yaitu dengan mensejahterakan kehidupan guru, dan memberikan pelatihan dan sarana dalam meningkatkan profesionalisme dari guru, sehingga proses dalam pengajaran dalam pendidikan dapat tercapai sesuai dengan tujuan yang telah ditentukan. Dalam artikel ini dibahas apa profesionalisme guru, faktor yang mempengaruhi profesional guru dan upaya dalam peningkatan profesionalisme guru, kegiatan supervisi dilakukan untuk sebagai proses pemecahan masalah yang ada dalam proses pembelajaran.
\end{abstract}

\section{A. Latar Belakang}

\section{Pentingnya Pelaksanaan Supervisi}

Komponen dalam proses pembelajaran guru adalah suatu komponen organik yang sangat menentukan. Tidak ada satu pun kualitas dalam pembelajaran tanpa adanya kualitas guru. Apapun segala sesuatu yang dilakukan oleh pemerintah pasti ada peningkatan kualitas dari kinerja guru sehingga peningkatan kualitas pembelajaran tidaklah mungkin dapat ada tanpa peningkatan kualitas dari para gurunya. 
Sumber daya manusia yang menentukan keberhasilan dalam suatu proses pembelajaran adalah guru. Guru adalah komponen pendidikan yang mempunyai hubungan sangat dekat dengan peserta didik dalam prose pengajaran sehari-hari disekolah, dan guru juga lah yang berperan dalam menentuka peserta didik dalam kegiatan sehari-hari untuk pencapai tujuan yang telah ditentukan.

Pemberdayaan profesi guru dapat dilakukan melalui pengembangan diri yang dapat dilakukan secara berkeadilan, tidak diskriminatif, demokratis, dan berkelanjutan dengan menjunjung tinggi hak asasi manusia, nilai kultural, nilai keagamaan, kode etik profesi dan kemajemukan bangsa. Kegiatan supervisi akademik adalah salah satu cara yang dapat dilakukan dalam program memperdayakan guru.

Supervisi akademik adalah suatu rangkaian proses kegiatan yang membantu guru untuk mengembangkan atau meningkatkan kemampuannya dalam mengelola proses dari pembelajaran guna untuk mencapai suatu tujuan akademik yang telah ditentukan. Kepala sekolah harus memiliki kompeten dalam melakukan supervisi akademik terhadap para guru yang kepala sekolah pimpin. Jadi seorang guru yang mempunyai keinginan untuk menjadi seorang kepala sekolah perlua adanya mengikuti program pendidikan atau pelatihan pelatihan supervisi akademik dalam rangka meningkatkan profesionalisme guru.

\section{Rumusan Masalah}

Adapun rumusan masalah dalam artikel ini adalah bagaimana peran supervisi akademik dalam peningkatan profesionalisme guru?

\section{Tujuan Pembahasan}

Adapun tujuan penulisan dari artikel ini terkait dengan rumusan masalah diatas yaitu untuk mengetahui peran supervisi akademik dalam peningkatan profesionalisme guru. 


\section{B. Kajian Literatur}

\section{Pengertian Profesionalisme Guru}

Menurut Kamus Besar Bahasa Indonesia (KBBI), Profesionalisme adalah mutu, kualitas, dan tindak tanduk yang merupakan ciri suatu profesi atau orang yang profesional. Jadi profesionalisme guru adalah mutu, kualitas, dan tindak tanduk dari sesorang guru yang profesional.

Guru adalah seseorang pendidik profesional yang mempunyai tugas utama mengajar, mendidik, menilai, melatih, dan melakukan evaluasi terhadap peserta didik.

Profesionalisme guru merupakan arah, nilai, kondisi, kualitas dan tujuan suatu kewenangan dan keahlian dalam bidang pendidikan dan proses pengajaran yang berkaitan dengan pekerjaan seseorang yang menjadi mata pencaharian. Dan sedangkan guru yang profesional yaitu seseorang guru yang memiliki wawasan atau kompetensi yang menjadi syarat untuk melakukan suatu tugas pengajaran dan pendidikan.

\section{Faktor-faktor yang mempengaruhi guru profesional}

Adapun faktor-faktor yang mempengaruhi guru profesional adalah sebagai berikut:

\section{a. Status Akademik}

Untuk menciptakan tenaga profesional pada dasarnya sekolah dikembangkan dan dibina dari berbagai segi yaitu sebagai berikut:

1. Segi praktis

Segi praktis disini dapat diartikan dengan berdasarkan pada praktek adalah cara melakukan apa yang tersebut dalam teori (w.j.s Porwadarminta 1999:99).

2. Segi teoritis

Disekolah atau dilembaga-lembaga keguruan yang membina dan menciptakan tenaga-tenaga profesional diberikan ilmu-ilmu pengetahuan yang harus disampaikan kepada anak 
didik, juga diberikan ilmu-ilmu pengetahuan khusus untuk menunjang keprofesionalnya seorang guru.

\section{b. Pengalaman Belajar}

Dalam menghadapi anak didik sangatlah tidak mudah untuk mengorganisir peserta didik, ada banyak keluhan yang dihadapi, dan banyak juga dijumpai seorang guru yang mengeluh karena sulit untuk menciptakan proses pembelajaran yang efektif dan menyenangkan.

\section{c. Mencintai Profesi sebagai Guru}

Rasa cinta akan mendorong individu untuk melakukan suatu pengorbanan atau usaha. Apabila sesorang melakukan suatu pekerjaan tanpa rasa cinta bisa jadi ada paksaan dari orang lain, maka dalam melakukan sesuatu pekerjaan mereka terpaksa. Dalam melakukan pekerjaan akan berhasil apabilla disertai dengan raa cinta terhadap pekerjaan yang ingin dilakukan.

\section{d. Berkepribadian}

Kepribadian yaitu seluruh atau keseluruhan sifat-sifat yang merupakan watak-watak seseorang, dalam proses pembelajaran kepribadian dari seorang pendidik atau guru juga menentukan terhadap kepribadian siswa atau anak didiknya.

\section{Peran Guru Profesionalisme dalam Proses Belajar Mengajar}

Proses yaitu beberapa aktivitas atau rangkaian kegiatan yang terjadi atau berlangsung sesuatu dari awal sampai akhir, maka suatu proses adalah suatu rangkaian yang tidak dapat dipisahkan dari suatu fungsi manajemen.

Ada empat proses administrasi menurut Luther Gullick yaitu:

a. Planning (Perencanaan) 
Perencanaan yaitu rincian dari garis besar untuk mempermudah dalam melakukan dalam melaksanakan dan metode yang digunakan dalam menyelesaikan suatu tujuan yang ingin dicapai.

b. Pengorganisasian

Yaitu proses penetapan struktur atau bagian formal dari beberapa kewenangan dimana suatu pekerjaan yang akan didelegasikan atau yang akan dibagi-bagi, dikoordinasi dan ditentukan untuk mencapai tujuan yang ingin dicapai.

c. Menyusun Pegawai

Yaitu keseluruhan fungsi dari kepegawaian sebagai usaha dari pelaksanaan memelihara situasi dan melatih para staff dan menciptakan siatuasi pekerjaan yang menyenangkan.

d. Pembinaan Kerja

Directing adalah salah satu tugas yang dilakukan secara terus menerus dalam proses pengambilan keputusan, atau suatu instruksi atau perintah untuk bertindak sebagai pemimpin dalam suatu organisasi.

e. Pengkoordinasiaan

Yaitu suatu kewajiban yang penting untuk menghubungankan berbagai kegiatan dalam suatu pekerjaan.

f. Pelaporan

Pelaporan yaitu seorang pemimpin yang bertanggung jawab harus apa yang telah atau yang sedang dilakukan, baik keperluan pimpinan atau karyawan dalam melaksanakan suatu pekerjaan.

g. Anggaran 
Anggaran atau badgeting yaitu keseluruhan biaya atau anggaran atau pembayaran dalam suatu pekerjaan.

\section{Upaya-upaya untuk Meningkatkan Profesinalisme Guru}

Menurut muhson (muhson, 2004) Profesionalisme Guru yaitu pedoman atau acuan yang sangat penting dalam peningkatan dunia pendidikan. Upaya-upaya untuk meningkatkan profesionalisme guru yaitu:

\section{a. Peningkatan Kesejahteraan}

Lebih mensejahterakan kehidupan guru dan lebih meningkatkan status sosial guru. Guru akan lebih dihormati dan dikagumi oleh peserta didiknya. Jika peserta didik mengagumi pendidiknya maka akan memotivasi belajar siswa dan pendidikan akan lebih berhasil.

\section{b. Kurangi Beban Guru}

Yaitu mengurangi beban guru dalam tugas-tugas administrasi yang sangat menyiksa waktu dari seorang guru. Dan sebaikmya dibuat oleh sebuah tim atau diknas atau musyawarah guru mata pelajaran (MGMP).

\section{c. Penyelenggaraan Pelatihan dan Sarana}

Usaha lain yang dapat meningkatkan profesionalisme guru yaitu denga memperdalam materi pelajaran dan melakukan pelatihan-pelatihan, memberikan kesempatan guru untuk mengikuti pelatihan dan membiayai atau melengkapi sarana dan prasarana yang dibutuhkan guru.

\section{Pembahasan atau Kajian Analitis}

Supervisi pendidikan yaitu suatu mengkoordinir, menstimulir, dan membimbing secara kontiniu pertumbuhan dan perkembangan guru-guru disekolah baik secara individual maupun kolektif, agar lebih efektif dan mengerti dalam meningkatkan dan mewujudkan seluruh fungsi pengajaran, 
dengan itu mereka dapat membimbing pertumbuhan murid agar lebih bisa berpartisipasi dalam dunia modern natinya (Bordman Et. Al, 1953:5).

Supervisi dilakukan setiap lini dalam sebuah organisasi, termasuk organisasi didalam ranah atau lingkup dunia pendidikan, salah satunya adalah sekolah. Supervisi adalah sebagai suatu kegiatan dari pimpinan sekolah yang ditujukan untuk perkembangan kepemimpinan guru-guru dalam mencapai suatu tujuan dari organisasi (Purwanto, 2005:76).

Menurut Sabandi (sabandi, 2013) Supervisor memegang peranan penting dalam meningkatkan kualitas guru agar melaksanakan pembelajaran yang lebih berkualitas dan supervisor disekolah meliputi sekolah dan pengawas. Sering dijumpai kepala sekolah melaksanakan supervisi akademik dengan hanya membawa kesekolah intrumen untuk mengukur kinerja. Perilaku demikian tidak akan dapat meningkatkan kualitas unjuk kerja guru dalam mengelola proses pembelajaran.

Supervisi akademik adalah beberapa atau rangkaian kegiatan yang membantu guru mengembangkan kemampuannya dalam mengelola pencapaian tujuan dan proses pembelajaran.

Hal-hal yang harus diperhatikan oleh supervisor dalam melaksanakan supervisi akademik yaitu:

1. Harus mampu menciptakan hubungan kemanusiaan yang harmonis.

2. Harus dilakukan secara berkesinambungan

3. Harus demokratis

4. Program supervisi harus integral dengan dunia pendidikan

5. Komprehensif

6. Konstruktif

7. Dan harus objektif

Beberapa kompetensi dalam kinerja guru yaitu sebagai berikut:

1. Kompetensi pedagogik

2. Kompetensi kepribadian 
3. Kompetensi sosial

4. Kompetensi profesional

Seorang guru harus dapat melakukan pembaharuan dan menguasai materi pembelajaran yang akan diberikan kepada siswa. Dengan mencari infromasi dari berbagai sumber.

\section{Kesimpulan dan saran}

\section{Kesimpulan}

Supervisor memegang peranan penting dalam meningkatkan kualitas guru agar melaksanakan pembelajaran yang lebih berkualitas dan supervisor disekolah meliputi sekolah dan pengawas. Sering dijumpai kepala sekolah melaksanakan supervisi akademik dengan hanya membawa kesekolah intrumen untuk mengukur kinerja. Perilaku demikian tidak akan dapat meningkatkan kualitas unjuk kerja guru dalam mengelola proses pembelajaran.

Beberapa kompetensi dalam kinerja guru yaitu sebagai berikut:

1. Kompetensi pedagogik

2. Kompetensi kepribadian

3. Kompetensi sosial

4. Kompetensi profesional

\section{Saran}

Makalah ini dijadikan awal proses pembelajaran agar dikesempatan berikutnya makalah ini menjadi lebih baik, baik secara teori dan pembahasan yang belum tercapai. Apabila dalam penyusunan makalah ini terdapat suatu kekurangan, maka saya sebagai penyusun menerima dengan apabila ada kritik, dan saran dari pembaca guna kesempurnaan dari makalah selanjutnya. 


\section{REFERENSI}

muhson, ali. (2004). meningkatkan profesionalisme guru: sebuah harapan. $\begin{array}{llll}\text { Pedagogi, } & \text { 2(1), } & 9 & \text { Retrieved }\end{array}$ https://journal.uny.ac.id/index.php/jep/article/view/665

sabandi, ahmad. (2013). supervisi pendidikan untuk pengembangan profesionalitas guru berkelanjutan. Pedagogi, XIII(2), 9. Retrieved from http://ejournal.unp.ac.id/index.php/pedagogi/article/view/4275 